\title{
THE CASE AGAINST THE CONSTITUTIONALITY OF THE SOCIAL SECURITY ACT
}

\author{
Charles Denby, Jr.*
}

The purpose of this article is to set forth briefly and as simply as possible the reasons for believing that at least the major provisions of the Social Security Act are unconstitutional. As a background for the discussion, a brief review of the history of the legislation is necessary.

Priar to the depression of I9zI, there was in this country no movement of any importance for social insurance. Workmen's compensation laws and factory laws regulating the hours of employment of women and children and the installation of safety devices were familiar, but compulsory unemployment insurance had hardly been heard of and, although there were a few private pension plans in existence, statewide old-age pensions had just begun to be mentioned. But the war had left us with a highly developed industrial system and the problem of old-age dependency and the problems created by the shortening of the useful life of the industrial worker had already become felt as a consequence. The short depression of Ig2I drew attention to these problems and to the related one of unemployment. Various states began to experiment with old-age assistance laws and there was even a feeble movement in favor of compulsory unemployment "insurance." The attention of the public was, however, not drawn to these problems until after the current depression was well under way.

By 1932, twenty-one states had adopted old-age assistance laws. They were a modified form of poor relief legislation, giving benefits based upon need. All of these laws followed the same general pattern: they provided for grants to aged indigent persons, the amount of the allowance being determined in each case by the need of the individual beneficiary, but being limited in nearly all cases to $\$ 30.00$ per

- A.B., 1922, Princeton; LL.B., r925, Harvard University. Member of the Pennsylvania Bar. Chairman, Pennsylvania State Committee on Unemployment Reserves, I933; Chairman, Committee on Unemployment Insurance Law, American Bar Association, 1934-35. Legal Secretary to Mr. Justice Holmes; 1925-26.

${ }^{1}$ The term "unemployment insurance" is popularly, though inaccurately, used to include both "reserve" plans, in which employers are compelled to maintain reserves available to their employees only "and "pooled fund" plans, which partake of the nature of insurance, in which contributions are made into a central pool or fund, available for payment of benefits to all employees covered by the plan. Hence the neutral term, "unemployment compensation" used in the Social Security Act, and including both forms, is more satisfactory. 
month. Experience with these laws was successful in many states; and although there was the inevitable opposition from die-hard employing interests, these laws were becoming recognized as a desirable form of social legislation consistent with American principles. ${ }^{2}$

During the first two years of the depression, agitation for so-called unemployment insurance also gained momentum. Wisconsin adopted an American version of the continental system of unemployment insurance and in I93I enacted the first unemployment reserve law to be adopted in this country. ${ }^{3}$ The matter was studied by legislative committees in a number of other states and by most of them the principle of unemployment insurance was approved and the enactment of legislation of this character recommended. ${ }^{4}$ There are, however, grave doubts as to the efficacy of so-called unemployment insurance, and much respectable opinion that it is a fallacious remedy, the adoption of which will do more harm than good.5 Under the circumstances, many felt that a system so novel and untried in America should not be hastily adopted, and should first be subjected to practical test in a few states before being adopted everywhere.

With the advent of the New Deal, however, the principle of experimentation within state boundaries and the gradual development of a national policy was superseded by that of impetuous action on a grand scale. Accordingly, the Social Security Act, ${ }^{6}$ called one of the cornerstones of the new order, contemplates the setting up, practically at one stroke, of a social insurance program on a national scale.

\section{I}

In addition to providing comparatively unimportant grants to the states to assist them in financing their own plans for aid to the blind, to dependent children and for maternal and child welfare, and in addition to making appropriations for federal public health work, the Social Security Act contains three major features: (I) Title I, making grants to states having old-age assistance laws which comply with certain specifications; (2) Titles II and VIII, setting up a full-fledged old-age pension system, federally financed and federally administered; and (3) Title IX, imposing payroll taxes designed to force the adoption by all of the states of unemployment compensation laws meeting standards specified in the Act.

Title I appropriates sums sufficient to match sums expended by the states pursuant to approved old-age assistance plans, provided that the federal liability shall not be in excess of $\$ 15.00$ per month per beneficiary. To entitle a state to the financial as-

2See the writer's article, Do We Need Old Age Pensions? Yes (1933) 170 Annals 93.

${ }^{3}$ Wis. Laws I93I (Spec. Sess.) c. 20 . The act went into effect July 1, 1934.

- Particularly helpful reports favoring an unemployment reserve system were prepared by the Massachusetts, Minnesota and New York Commissions. The Ohio Commission favored a pooled fund. The Pennsylvania Commission, of which the writer was Chairman, was divided; half the members opposing compulsory unemployment compensation in any form.

${ }^{5}$ See the writer's testimony in opposition to the Wagner-Lewis Bill. Hearings before a Subcommittce of the House Committee on Ways and Means on H. R. 7659, 73rd Cong., 2d Sess. (1934) at pp. 359-388.

'Act of Aug. 14, 1935, 49 STAT. 620. 
sistance provided in Title I, the state plan must be compulsory in all political subdivisions of the state, must provide for financial participation by the state and either state administration or state supervision, by methods of administration satisfactory to the Social Security Board; must provide for a hearing to applicants denied assistance; must provide for making periodic reports to the Social Security Board and must provide that if, upon the death of any recipient of old-age assistance, the state shall collect anything from his estate, one-half of the amount so collected shall be paid to the United States. Furthermore, in order to be approved, the state law may not impose as a condition for eligibility for assistance an age requirement of more than 65 years, a residence requirement which excludes a person who has resided in the state for five out of nine years preceding his application and for one year immediately preceding the application, or a citizenship requirement which excludes a citizen of the United States.

Title II establishes a complete system of old-age pensions, applicable broadly to all employees in the United States, including salaried corporate officers, except those engaged in agricultural labor, domestic service, government employment and employment by charitable organizations." The system is wholly under federal administration, and the Federal Act stipulates the benefits, the method of their payment and all other matters relating to the administration of the law. Title VIII provides the funds for building up the reserve from which the benefits are to be paid. These funds are provided by employers and their employees in equal proportions, by imposing on the latter an "income tax" and, on the former, an "excise tax," fixed in both cases by a percentage of payroll.

It will be seen that the foregoing provisions furnish a complete system of relief for old-age- dependency. Although Title II provides what is in effect a compulsory saving plan with respect to a group which comprises nearly two-thirds of all gainfully employed persons in the United States, ${ }^{\top}$ Title I is a necessary complement thereto, for two reasons: first, to care for needy aged persons who fall within the groups excluded from the federal pension plan; second, to care for those who are already advanced in years, and will therefore not be able to build up an adequate pension to secure them from dependency when they reach 65 .

Title IX is of a different character. The principal hurdle to the enactment of state unemployment compensation laws was felt to be that of interstate competition: the argument being that a state enacting such a law was imposing upon its employers a burden which would place them at a competitive disadvantage with those of states which did not adopt such laws. The same argument had been urged against workmen's compensation laws and child labor laws. Title IX is designed to do away with this argument. It imposes an "excise tax" upon those who employ eight or more persons in employments other than approximately the same as are exempted from

'Data prepared under the direction of the Secretary of the Treasury at the request of Senator Jesse H. Metcalf, and submitted to the Senate Committee on Finance, indicate that approximately 25,200,000 gainfully employed persons will be subject to the tax under Title VIII in the year 1937. 
the provisions of Titles II and VIII. Against this tax, however, is allowed a credit equivalent to the maximum payments such employers must make pursuant to approved state unemploymentycompensation laws, even though less than the applicable maximum may have become due because of favorable unemployment experience. But the total credit may not exceed 90 per cent of the federal tax. In order to be approved, a state law must comply with specifications set forth in the Act. Among these is a requirement that all monies paid into the state fund shall be paid over to the United States Treasury for investment and administration. The net effect of this section is that while employers in states which have adopted no unemployment insurance laws must pay the full tax to the Treasury, their employees can receive no benefits whatever; and that employers who have been compelled to make payments pursuant to a state unemployment law which does not meet federal specifications will have to pay the federal payroll tax nevertheless. That a tax of this sort will be most effective in inducing the desired state action can hardly be doubted.

We have, therefore, for consideration a law-or a group of laws combined into one-which (I) grants financial assistance to states in carrying out their poor relief laws, provided that these laws meet a pattern prescribed by Congress; (2) sets up a nation-wide compulsory pension system, applicable to all industrial employment; and (3) imposes taxes so designed as to exert strong pressure upon state legislatures to adopt unemployment compensation laws.

\section{II}

In approaching the consideration of the constitutionality of any federal law, the essential consideration is that the federal government is a government of delegated powers. To make certain that these powers should not be exceeded, the Tenth Amendment expressly provides that

"All powers not delegated to the United States by the Constitution, nor prohibited by it to the States, are reserved to the States respectively, or to the people."

Accordingly, the federal government has only such powers as are expressly conferred upon it by the Constitution and such as are reasonably implied from those granted. $^{8}$ Thus, the express power to regulate interstate commerce has been held to carry with it, not only the power to regulate matters clearly interstate in character, but also the implied power to regulate matters otherwise of only local concern, if they directly affect interstate commerce. ${ }^{9}$ So, the power to borrow money, to lay and

${ }^{8}$ McCullough v. Maryland, 4 Wheat. 316, 407 (U. S. 1819); Martin v. Hunter's Lessec, I Wheat. 304 , 326 (U. S. I 816 ).

${ }^{8}$ Such matters are the regulation of intrastate railway rates to the extent that they affect interstate rates: Houston E. \& W. T. R. Co. v. U. S., 234 U. S. 342 (I913); Railroad Comm. v. Chicago, B. \& Q. R. Co., 257 U. S. 563 (I921); regulation of local conspiracy to obtain a corner on the interstate cotton market: U S. v. Patten, 226 U. S. 525 (1913); regulation of local trading in futures in interstate grain market: Board of Trade v. Olsen, 262 U. S. I (I922). So also, temporary or transitory local transactions are subject to federal regulation where they are integral parts of a broader interstate transaction, as distribution of films from interstate commerce by local distributors: Binderup v. Pathe Exchange, 263 U. S. 29x (1923); sale of cattle shipped in from without the state, from local stockyards: Swift \& Co. v. U. S., 196 U. S. 375. (I905); Iegulation of local dealers in such cattle; Stafford v. Wallace, 258 U. S. 495 (I922). 
collect taxes and to pay the public debt, involves, as a necessary and proper incident, the power to establish a national bank. ${ }^{10}$ This, in turn, carries with it the power to authorize such banks to engage in the normal functions of a bank-most of which are, in themselves, local in character; ${ }^{11}$ and even to confer trust powers upon national banks, in order that they shall not be at a disadvantage in competing with statechartered competitors. ${ }^{12}$ By a logical extension of the same principle, Congress was held to have been within its powers in the enactment of the Federal Farm Loan Act, the principal purpose of which was to permit the loaning of money upon farm lands on favorable terms, on the ground that the Federal Land Banks created under the authority of that Act were designated depositaries of public money and financial agents of the government. ${ }^{13}$

So long as the federal government is acting within its proper sphere, however, it is supreme. Its activities cannot be limited or interfered with by the states. Accordingly,

"When Congress acts within the limits of its Constitutional authority, it is not the province of the judicial branch of the government to question its motives." 14

Conversely, however, the power of the states to regulate their purely internal affairs has never been surrendered to the federal government and cannot be interfered with by the latter. The maintenance of this balance is essential to the preservation of our dual system of government and is one of the safeguards of traditional American liberty.

The conflict between the foregoing principles has been one of the chief concerns of constitutional interpretation. If the only limitations upon the gradual extension of federal power were those of logic alone, there would soon be such an encroachment upon the reserved powers of the states that the latter would be entirely whittled away; and we would awake to find ourselves to all intents and purposes wholly under a central government and impotent in local affairs. That this danger was foreseen by the framers of the Constitution, and that they deliberately sought to guard against it, is nowhere stated more forcefully than in the following passage from an opinion of the Supreme Court in a case in which it rejected the contention that there are legislative powers affecting the nation as a whole which belong to, although they are not expressed in, the grant of powers. In reiterating that the federal government is one of enumerated powers, and that this proposition, although clear from the Constitution itself, was reasserted by the Tenth Amendment, the Court said that

"This amendment, which was seemingly adopted with prescience of just such contention as the present, disclosed the widespread fear that the National Government might, under the pressure of a supposed general welfare, attempt to exercise powers which had

\footnotetext{
${ }^{20}$ Osborn v. Bank of U. S., 9 Wheat. 738 (U. S. 1824).

${ }^{21}$ McCulloch v. Maryland, 4 Wheat. 316 (U.S. 1819).

${ }^{12}$ First Nat. Bank v. Fellows, 244 U. S. 4 I6 (I9ry).

${ }^{23}$ Smith v. Kansas City Title \& Tr. Co., 255 U. S. I 80 (1921).

"Id. at 210 .
} 
not been granted. With equal determination the framers intended that no such assumption should ever find justification in the organic act, and that if in the future further powers seemed necessary they should be granted by the people in the manner they had provided for amending that act."15

The possibilities of such an extension of the federal authority were never more graphically indicated than by the principal New Deal laws, all of which were sought to be sustained as logical extensions of granted federal powers; and which, had they been sustained, would shortly have reduced the states to mere administrative districts in a central government.

The principal argument to sustain these laws was the plea that the national emergency and changed economic conditions justified a wide extension of federal power. But the limits of constitutional authority apply under all circumstances and conditions. If an act is unconstitutional, neither an emergency nor a widely-felt economic necessity can justify it. ${ }^{16}$ That action by Congress is economically or otherwise highly desirable is immaterial in a consideration of federal power. Thus, in holding invalid the Railroad Retirement Act, an act having purposes similar to those of Title II of the Social Security Act, the Supreme Court said that

"though we should think the measure embodies a valuable social plan and be in entire sympathy with its purpose and intended results, if the provisions go beyond the boundaries of constitutional power we must so declare."17

Similarly, in holding invalid a tax, the purpose of which was to prevent the employment of child labor in manufacturing and mining industries, the Court said that it could not avoid this duty,

"even though it require us to refuse to give effect to legislation designed to promote the highest good."18

In. invalidating the N. R. A. Codes by unanimous action, the Court held that neither the existence of a "national crisis" demanding "a broad and intensive coöperative effort by those engaged in trade and industry," nor the existence of a "serious economic situation" could justify federal action beyond the scope of its delegated powers. ${ }^{19}$

Even if it be conceded, therefore, that a national system of social insurance is highly desirable; the unemployment and old-age dependency are national problems which cannot be solved by merely local action; that the problems of investment of reserves make separate state systems impractical; and that for other cogent and imperative reasons the Social Security Act is clearly necessary and desirable, these

\footnotetext{
${ }^{15}$ Kansas v. Colorado, 206 U. S. 46, 90 (1907).

${ }^{18}$ Schechter Poultry Corp. v. U. S., 295 U. S. 495, 529, 549 (1935).

${ }^{27}$ Railroad Retirement Board v. Alton R. R. Co., 295 U. S. 330,346 (1935).

${ }^{18}$ Bailey v. Drexel Furniture Co., 259 U. S. 20, 37 (1922).

${ }^{20}$ Supra note 15 .
} 
reasons do not justify the Act. ${ }^{20}$ Although an Act of Congress enjoys every presumption of constitutionality, ${ }^{21}$ nothing less than clear constitutional authority can sustain this or any other Act of Congress.

In order to sustain the various provisions of the Social Security Act, it is therefore necessary to find an express or implied grant of federal power of which each of these provisions is an exercise.

The only powers which might possibly come in question are the power to regulate commerce among the several states, the power to lay and collect taxes and excises, or the related power to use funds raised through taxation to provide for the general welfare of the United States.

It will, therefore, be necessary to examine the commerce, taxing and general welfare powers to determine whether directly or by implication they sustain the Act.

\section{III}

None of the provisions of the Social Security Act can be justified as an exercise of the commerce power. It is true that this power is one of the widest at the disposal of the federal government. As has been pointed out, it permits Congress to regulate not only interstate commerce as such, but also matters normally of merely local concern, where they have a direct effect upon interstate commerce. But when Congress sought to make what appeared to be a logical extension of the commerce power by passing a law prohibiting the transportation in interstate commerce of articles manufactured by child labor, the law was declared unconstitutional. The Court held that manufacturing and mining are not commerce and could not be directly regulated by Congress; that otherwise harmless articles of commerce do not become harmful merely because manufactured by. child labor, and that Congress' power to exclude injurious articles from interstate commerce does not justify the exclusion of such goods. The essence of the decision is the holding that if the act in question could be upheld,

"all manufacture intended for interstate shipment would be brought under federal control to the practical exclusion of the authority of the States, a result certainly not contemplated by the framers of the Constitution. ...."22

The logic of the decision has rightly been questioned; ${ }^{23}$ but its ultimate soundness seems clear. To have sustained the law in question would have led inevitably

${ }^{20}$ The Act establishes a long-term program and cannot be characterized as emergency legislation, but, even if this were attempted, its constitutional position would not be strengthened. Home Building \& Loan Assn. v. Blaisdell, 290 U. S. 398 (1934); Ex parte Milligan, 4 Wall. 2 (U. S. 1866). In the former case the Court said (at p. 425): "Emergency does not create' power. Emergency does not increase granted power or remove or diminish the restrictions imposed upon power granted or reserved. The Constitution was adopted in a period of grave emergency. Its grants of powér to the Federal Government and its limitations of the power of the States were determined in the light of emergency and they are not altered by emergency. What power was thus granted and what limitations were thus imposed are questions which have always been, and always will be, the subject of close examination under our constitutional system."

${ }^{n}$ So also will it be construed, if fairly possible, so as to avoid the conclusion that it is unconstitutional, U. S. v. Jin Fuey Moy, 24 I U. S. 394 (1916), and every reasonable construction will be resorted to to that end. Hooper v. California, 155 U. S. 648 (I895).

Hammer v. Dagenhart, 247 U. S. 251, 272 (r917).

See Corwin, The Twilight of the Supreme Court (1934) 26 et seq. 
to virtually complete surrender of state authority in matters of domestic concern; for, granted the validity of this law, there could be no logical limit to the extent of this indirect control over local affairs.

Finally, the Court rejected the argument that the law should be sustained as an aid to the more liberal states in maintaining their labor standards; as a protection, in other words, from interstate competition. Of this argument, the Court said,

"In other words [the Government argues] that the unfair competition, thus engendered, may be controlled by closing the channels of interstate commerce to manufacturers in those States where the local laws do not meet what Congress deems to be the more just standard of other States.

"There is no power vested in Congress to require the States to exercise their police power so as to prevent possible unfair competition. Many causes may coöperate to give one State, by reason of local laws or conditions, an economic advantage over others. The Commerce Clause was not intended to give to Congress a general authority to equalize such conditions." 24

The decision in this case was reached by a narrowly divided court, and the extent of its authority was for some years in doubt. But since the recent decision unanimously holding the N. I. R. A. to be unconstitutional, there can no longer be any doubt that a merely limited effect upon interstate commerce cannot justify the federal regulation of local concerns. In that case, it was unanimously held that the indirect effect of hours and wages in local employment upon interstate commerce was too remote to justify federal regulation of hours and wages in local enterprise. As was stated in the opinion of the Chief Justice,

"Interstate commerce is brought in only upon the charge that violations of [the provisions of the live poultry code]-as to hours and wages of employees and local sales'affected' interstate commerce.

". . . But where the effect of intrastate transactions upon interstate commerce is merely indirect, such transactions remain within the domain of state power. If the commerce clause were construed to reach all enterprises and transactions which could be said to have an indirect effect upon interstate commerce, the federal authority would embrace practically all the activities of the people and the authority of the State over its domestic concerns would exist only by sufferance of the federal government. . . .

"The question of chief importance relates to the provisions of the Code as to the hours and wages of those employed in defendants' slaughterhouse markets. It is plain that these requirements are imposed in order to govern the details of defendants' management of their local business. The persons employed in slaughtering and selling in local trade are not employed in interstate commerce. Their hours and wages have no direct relation to interstate commerce." 25 -

So also did the Court reject again the interstate competition argument:

"The Government also makes the point that efforts to enact state legislation establishing high labor standards have been impeded by the belief that unless similar action is taken generally, commerce will be diverted from the States adopting such standards, and that

${ }^{24}$ Hammer v. Dagenhart, supra note 22 , at 273.

${ }^{25}$ Schechter Poultry Corp. v. U. S., 295 U. S. 495, 546, 548 (1935). 
this fear of diversion has led to demands for federal legislation on the subject of wages and hours. The apparent implication is that the federal authority under the commerce clause should be deemed to extend to the establishment of rules to govern wages and hours in intrastate trade and industry generally throughout the country, thus overriding the authority of the States to deal with domestic problems arising from labor conditions in their internal commerce.

"It is not the province of the Court to consider the economic advantages or disadvantages of such a centralized system. It is sufficient to say that the Federal Constitution does not provide for it."26

It is, therefore, hopeless to try to sustain the Social Security Act as an exercise of the commerce power.

\section{IV}

The taxing power of the United States is almost unlimited, except for specific limitations not here material, so long as the imposition is in fact a tax. If, however, the "tax" is a tax in form only, and really is a regulation, under the guise of a tax, of matters which the federal government has no power to regulate directly, then the tax will be held to be invalid.

Here again is the problem of limiting the logical extension of an admitted power, in order to preserve the authority of the states and our dual system.

How far the Court would go in declaring invalid an act which on its face imposes a tax, but which at the same time has the effect of regulating a matter beyond the scope of federal regulation, was for many years not clear. In early cases, the Court had sustained a prohibitory tax upon the circulating notes of persons and of state banks, though the act seemed clearly intended to prevent the circulation of such notes in competition with national bank notes. ${ }^{27}$ Later, the Court sustained a prohibitory tax on oleomargarine, holding that it was within the discretion of Congress of levy excise taxes although the effect of such tax might incidentally be oppressive or even destructive.28 Finally, the Court sustained the Harrison Narcotic Drug Act, which imposed a special tax on the manufacture, importation, sale or gift of narcotics, but the real purpose of which was obviously to regulate dealings in narcotics and to confine them to registered dealers and physicians. ${ }^{29}$

The principle of the foregoing cases, logically extended, would permit almost unlimited indirect regulation through the imposition of burdensome taxes. In the Child Labor Tax Case, ${ }^{30}$ however, the Court put a limit to this process of extension.

After it had been held that the commerce power did not permit Congress directly to prohibit the transportation in interstate commerce of goods manufactured by child labor, Congress endeavored to accomplish the same end by an ostensible resort to the taxing power. It imposed an "excise tax" of ro per cent of all net profits of mines, quarries, mills and other manufacturing establishments which employed children

${ }^{2}$ Id. at 549 .

${ }^{27}$ Veazie Bank v. Fenno, 8 Wall. 533 (U. S. 1869 ).

2 McCray v. U. S., I95 U. S. 27 (I904). 20 U. S. v. Doremus, 249 U. S. 86 (I9Ig).

${ }^{30}$ Bailey v. Drexel Furniture Co., 259 U. S. 20 (I922). 
under the ages or for more than the hours specified in the Act. Although the Act was on its face a taxing statute, the Court held that it obviously was intended as a regulation of child labor:

"Its prohibitory and regulatory effect and purpose are palpable. All others can see and understand this. How can we properly shut our minds to it?

"... Grant the validity of this law, and all that Congress would need to do hereafter, in seeking to take over to its control any one of the great number of subjects of publiç interest, jurisdiction of which the states have never parted with, and which are reserved to them by the Tenth Amendment, would be to enact a detailed measure of complete regulation of the subject and enforce it by a so-called tax upon departures from it. To give such magic to the word 'tax' would be to break down all constitutional limitation of the powers of Congress and completely wipe out the sovereignty of the States." 31

The Court concluded that

"the so-called tax is a penalty to coerce people of a State to act as Congress wishes them to act in respect of a matter completely the business of the state government under the Federal Constitution." 32

Similarly, the Court held that the Future 'Trading Act of $192 \mathrm{r}$, imposing a prohibitive tax upon all contracts of sale of grain for future delivery, except only those made by farmers or farmers' coöperative associations and those made by members of a Board of Trade which had been designated by the Secretary of Agriculture as a "contract market," was not in fact a taxing act but an act designed to bring grain markets under federal regulation. In a unanimous opinion, the Court held:

" "The act-is in essence and on its face a complete regulation of boards of trade, with a penalty of 20 cents a bushel on all "futures" to coerce boards of trade and their members into compliance. When this purpose is declared in the title to the bill, and is so clear from the effect of the provisions of the bill itself, it leaves no ground upon which the provisions we have been considering can be sustained as a valid exercise of the taxing power'." 33

In determining whether a "taxing" act is in fact a revenue measure or is really enacted for an ulterior motive, the Court will consider the true purpose of the act, as reflected in its title ${ }^{34}$ and by a consideration of the circumstances leading to its enactment; ${ }^{35}$ the amount of the tax relative to the value of the thing taxed; ${ }^{86}$ whether the tax will tend to raise revenue; ${ }^{37}$ the degree to which the tax is related to a scheme of regulation; ${ }^{38}$ whether the regulatory features of the act, such as those requiring the keeping of records, etc., are consistent with the enforcement of a tax as such or really serve an ulterior purpose having nothing to do with the revenue features of the act; ${ }^{39}$ and whether the revenue raised by the act is designed for the support of the government, rather than for some other purpose. ${ }^{40}$

\footnotetext{
${ }^{81} I d$. at 37,38 . ${ }^{22}$ Id. at 39 .

s3 Trusler v. Crooks, 269 U.S. 475,480 (rg26), quoting from Hill v. Wallace, 259 U. S. 44, 66 (1922).

a Ibid.

${ }^{85}$ Bailey v. Drexel Furniture Co., supra note 30, at 39; U. S. v. Butler, 56 Sup. Ct. 3I2, 3 I6 (1936);

U. S. v. Constantine, 296 U. S. 287,294 (1935).

${ }^{\infty}$ Trusler y. Crooks, supra note 33 .

${ }^{29}$ Ibid.

${ }^{87}$ Ibid.; U. S. v. Butler, supra note 35.
${ }^{\approx}$ Linder v. U. S., 268 U. S. 5 (1925).

${ }^{10}$ U. S. v. Butler, supra note 35; Head Moncy Cases, I12 U. S. 580 (I884).
} 
In the light of the foregoing, and of the history and purpose of the legislation, it can hardly be seriously contended that the Social Security Act is a taxing statute. By none of the standards just mentioned can either Title VIII or Title IX be held to be a "tax." As was quite frankly stated by the Chairman of the Ways and Means Committee in reporting the bill for passage, the Act establishes a comprehensive plan of "social insurance" against " (I) unemployment; (2) old age, (3) lack of a breadwinner in families with young children." 41 Similarly, the purpose of Title IX could not be stated more clearly than in this passage from the Report of the Committee on Ways and Means:

"The failure of the States to enact unemployment insurance laws is due largely to the fact that to do so would handicap their industries in competition with the industries of other States. The States have been unwilling to place this extra financial burden upon their industries. A uniform, Nation-wide tax upon industry, thus removing this principal obstacle in the way of unemployment insurance, is necessary before the States can go ahead. Such a tax should make it possible for the States to enact this socially desirable legislation.

"This is one of the purposes of title IX of this bill." 42

Nor does either title tend to provide revenue for the general government. Clearly is this so of Title IX, since the credit features, embodied for the purpose above stated, will deprive the government of go per cent of the revenue produced. As for the income taxes and excise taxes imposed by Title VIII, they are not levies "for the support of the government." Although their proceeds are paid into the general funds of the Treasury, the relationship between Titles II and VIII makes it evident that thesẽ taxes are intended as contributions into a reserve fund which is to be used to pay pensions to specific individuals, with respect to whom such contributions were made. It is a compulsory saving plan, applicable to all industrial workers. No part of the reserve fund is used for governmental purposes except to a limited extent in the administration of the Social Security Act itself.

Moreover, even if Title VIII were an exercise of the taxing power, there is grave doubt whether the "excise tax" imposed upon the employers of the beneficiary employees is a valid charge, in view of the holding in the Railroad Retirement Act decision that an analogous feature of that Act was a violation of the Fifth Amendment to the Constitution, which prohibits the taking of property without due process of law. The Court held that the Act was unconstitutional on that ground, since the property of certain carriers would be taken to build up a fund used largely for the benefit of the employees of other carriers. The Court held that

"There is no warrant for taking the property or money of one and transferring it to another without compensation, whether the object of the transfer be to build up the equipment of the transferee or to pension its employees." 43

"79 CoNG. Rec. 5468 (1935).

${ }^{20}$ H. R. Rep. No. 615, 74th Cong., Ist Sess. (1935) p. 8.

${ }^{4}$ Railroad Retirement Board v. Alton R. R. Co., 295 U. S. 330, 357 (I935). The Railroad Retirement Act, it is true, required a "contribution" for pension purposes from the employer railroads, but it is 
The argument applies with equal force to the compulsory taking of property from employers to create a pension fund for their employees. And, as said by the Court in the $A . A$. $A$. decision with respect to processing taxes levied upon processors, the proceeds of which were to be paid to certain producers of agricultural products,

" $A$ tax, in the general understanding of the term, and as used in the Constitution, signifies an exaction for the support of the Government. The word has never been thought to connote the expropriation of money from one group for the benefit of another. We may concede that the latter sort of imposition is constitutional when imposed to effectuate regulation of a matter in which both groups are interested and in respect of which there is a power of legislative regulation. But manifestly no justification for it can be found unless as an integral part of such regulation." 14

As for Title IX, its obvious and admitted purpose is to equalize competitive conditions between states, insofar as a charge for unemployment compensation is concerned. That the imposition of a burden for such a purpose cannot be allowed, appears from the cases above cited. ${ }^{45}$

It seems clear, therefore, that the Social Security Act cannot be sustained as a taxing measure.

\section{$\mathrm{V}$}

The remaining constitutional authority upon which the provisions of the Social Security Act may be sought to be rested is the so-called "welfare clause." This famous clause ${ }^{46}$ provides that

"The Congress shall have power To lay and collect Taxes, Duties, Imposts and Excises, to pay the Debts and provide for the common Defence and general Welfare of the United States. ..."

From the beginning of the government, there has been protracted debate as to the true meaning and scope of this clause; authorities being divided as to whether the view of Madison or that of Hamilton, was correct. ${ }^{47}$ The former asserted that the latter part of the clause conferred no independent power, but related to the specific powers enumerated in the subsequent clauses of the same section; whereas Hamilton maintained that the clause conferred a separate and distinct power to appropriate revenues raised through taxation for the general welfare of the United States, and not merely in order to carry out the powers elsewhere expressly enumerated. The controversy appears finally to have been authoritatively resolved by the Supreme Court in the $A$. A. A. decision, in which the Court interprets the welfare clause as though it read

submitted that, from a constitutional standpoint, the fact that this levy was not designated as a tax is inconsequential. .

"U. S. v. Butler, 56 Sup. Ct. 312, 317 (1936).

${ }^{45}$ Supra notes $24,26$.

${ }^{4}$ U. S. Const. ARt. I, $\$ 8$.

${ }^{47}$ For an able summary of the historical background, see Corwin, The Spending Power of Congress (1923) 36 HARv. L. REv. 548 . 
"The Congress shall have power to lay and collect taxes, duties, imposts and excises; in order to provide funds with which to pay the debts and to provide for the common defense and general welfare of the United States."

and holds that the clause grants an independent substantive power. As said by the Court,

"It results that the power of Congress to authorize expenditure of public monies for public purposes is not limited by the direct grants of legislative power found in the Constitution." 48

In other words, the power of Congress to appropriate monies for the general welfare is a power of equal dignity and scope with the power to tax, the power to regulate commerce or any other of the granted powers. The limits of this power are not yet clear, however, and it has been little tested in the courts. It is beyond question, however, that the power is merely one to appropriate money in the interest of the general welfare. It does not justify general legislation in the interest of the general welfare. Such an interpretation was expressly rejected by the framers of the Constitution, ${ }^{49}$ and cannot be justified upon any rẹasonable ground. Not merely would such an interpretation do extreme violence to the context in which the clause is set, but it would make all the other provisions of the Constitution superfluous, and destroy the whole foundation of the dual system which it was the clear intention of the Constitution-to establish.

Any lingering doubt on this question has been disposed of by the opinion of the Court in the $A$. $A$. A. case. Expressly reserving the question whether an appropriation in aid of agriculture falls within the welfare clause, the Court holds that no such appropriation is valid if it is in real effect a regulation of agriculture.

So long as there is no question of ulterior result or motive, the power is without limit, except that the expenditure must be for the general welfare of the whole country. Thus, it has been held to justify appropriations to construct a national memorial park; ${ }^{50}$ and it seems clearly to justify appropriations which for years have been made to aid public education in the states and to establish and maintain the Bureau of Fisheries, the Bureau of Mines, the Department of Agriculture, and numerous similar activities, as well as to relieve the unemployed and the sufferers from drought, flood and other catastrophes. But the power conferred by the welfare clause necessarily has limitations similar to those imposed upon the powers to tax and to regulate commerce. Just as those powers may not be employed to serve an ulterior end which cannot be reached by the direct action of Congress, just as they cannot by "logical" extension be expanded into the sphere reserved to the states, so the power to appropriate monies for the general welfare of the United States cannot be used to serve an ulterior end which could not be directly attained.

\footnotetext{
${ }^{48}$ U. S. v. Butler, 56 Sup. Ct. 312, 319 (1936).

${ }^{20}$ See Story, Commentaries on the Constitution (1833) \$908.

${ }^{\infty}$ U. S. v. Gettysburg Ry. Co., I60 U. S. 668, 681 (1896).
} 
It would seem that this is the necessary consequence of the decision in the $A . A$.A. case. In form, that case involved the validity of processing taxes. In substance, however, the decision rests on the fact that these taxes were imposed to provide the revenue which in turn was to be used for the regulation of agriculture and the creation of a scarcity of agricultural products in order to raise the price level. The Supreme Court struck down the tax as part of this regulatory scheme. In itself, however, the tax was valid. It was invalid only because of the use to which the proceeds of the tax were to be put. In other words, not only is a tax invalid which, by imposing a penalty, directly results in regulation; but one is equally invalid which, though otherwise valid, is designed to provide money which is to be spent to attain an end which cannot be directly reached.

The $A . A$. $A$. decision went even further than this. It held that where Congress cannot directly regulate conduct and cannot regulate it indirectly through the imposition of a penalty, it cannot even appropriate public monies to purchase compliance with rules and regulations, obedience to which it could not enforce. As said by the Court,

"There is an obvious difference between a statute stating the conditions upon which monies shall be expended and one effective only upon assumption of a contractual obligation to submit to a regulation which otherwise could not be enforced. . . .

"Congress has no power to enforce its commands on the farmer to the ends sought by the Agricultural Adjustment Act. It must follow that it may not indirectly accomplish those ends by taxing and spending to purchase compliance." 52

Although strictly the $A . A$. A. case was decided as one involving the taxing power, the case is really one which for the first time foreshadows the limitations which will be placed upon the spending power. Though this is clear from the position of the majority, it is made abundantly so in the dissenting opinion written by Mr. Justice Stone and concurred in by Justices Brandeis and Cardozo. Justice Stone's dissent states at the outset that

"The present-levy is held invalid, not for any want of power in Congress to lay such a tax to defray public expenditures, including those for the general welfare, but because the use to which its proceeds are put it disapproved." 52

He proceeds to state that though the majority does not hold that the welfare clause does not justify aid to farmers, it does disapprove of aid which is given as "a step in a plan to regulate agricultural production." He concludes that such a limitation upon the spending power must virtually destroy it, and will certainly lead to "absurd consequences":

"The government may give seeds to farmers, but may not condition the gift upon their being planted in places where they are most needed or even planted at all. The government may give money to the unemployed, but may not ask that those who get it shall give labor in return, or even use it to support their families. It may give money to sufferers

${ }^{0}$ U. S. v. Butler, 56 Súp. Ct. 312, 316, 317 (1936).

Id. at 325 . 
from earthquake, fire, tornado, pestilence or flood, but may not impose conditions-health precautions designed to prevent the spread of disease, or induce the movement of population to safer or more sanitary areas. All that, because it is purchased regulation infringing state powers, must be left for the states, who are unable or unwilling to supply the necessary relief. The government may spend its money for vocational rehabilitation, 48 Stat. 389 , but it may not, with the consent of all concerned, supervise the process which it undertakes to aid. It may spend its money for the suppression of the boll weevil, but may not compensate the farmers for suspending the growth of cotton in the infected areas. It may aid state reforestation and forest fire prevention agencies, 43 Stat. 653, but may not be permitted to supervise their conduct. It may support rural schools, 39 Stat. 929, 45 Stat. II5I, $4^{8}$ Stat. 792 , but may not condition its grant by the requirement that certain standards be maintained." 53

Whether the proposition upon which the majority decision is rested is "absurd" or not is obviously a question of the degree to which it is to be extended. It is not difficult to state extreme hypothetical cases which will make any proposition seem absurd. What we are dealing with, however, is but another example of the great question at what point the purely logical extension of federal power must be limited by its infringement upon the fundamental proposition that our government is one of dual sovereignty. Ultimately, this point must be determined on the basis of the common sense, or of the social and political theories-or perhaps of the state of the digestion-of the Justices. In determining this point with respect to the commerce power, the taxing power, or any of the other federal powers, the same considerations come into play. In holding that most of the New Deal laws which have thus far come before the Court exceeded any admissible extension of federal power, it seems fairly clear that the Court was strongly influenced by the very magnitude and scope of the extension of federal power sought to be made by legislation enacted since I932.

In the light of what has been said, it is difficult to see how Titles II and VIII of the Social Security Act can stand as an exercise of the welfare power. That they must be read together is clear; and, read together, it is equally clear that they go far beyond an appropriation. They set up an elaborate system for compulsory saving. They regulate the relations between employers and employees in local industries, in mining, in clerical employments. They establish conditions of employment. None of these things can be reached directly by federal action; all are matters of state concern.

Title IX does not even purport to be an appropriation, and can therefore claim no support from the welfare clause.

Title I (and the similar Titles III, IV, V and X, making grants to the states for the administration of state unemployment compensation plans, for aid to dependent children, for maternal and child welfare and for aid to the blind) presents a more difficult question. Undoubtedly the objects of all these grants are well within the

${ }^{\text {ss } I d . ~ a t ~} 328$. 
"public welfare" clause and undoubtedly mere appropriations for such purposes would be valid.

The only question is whether the restrictions placed upon the grants in Title I (and the other similar titles) partake sufficiently either of a regulation of state affairs or of an attempt to coerce the states into action, to be an invalid exercise of federal power. Thus, the requirement of Title $I$, that, in order to justify federal grants, a state plan of old-age assistance must provide for financial participation by the state; that the administration of the state law must be satisfactory, so as to insure minimum costs of administration; that, of the amounts collected from the estates of deceased beneficiaries, one-half must be remitted to the United States, are reasonable conditions of a grant of federal aid. This is not quite so clear, however, of the requirement that the state law must be compulsory in all the political subdivisions of the state. In many, there is at present scope for local option. Why must this be given up? Nor is it quite so clear of the residence requirement imposed by Title I.

Whether any of the foregoing requirements are reasonable conditions, or whether they go beyond that, and are an attempt to control state policy on matters of state concern, is the question which must determine the validity of Title $I$. The question is obviously one of emphasis, of degree. The considerations influencing the decision are similar to those which determine whether the regulations contained in what purports to be a taxing act are, in fact, regulations reasonably related to the collection of the tax, or whether they go beyond that and contemplate the regulation of a matter over which Congress has no jurisdiction. ${ }^{54}$

That the provisions of these titles will result in tremendous pressure upon state legislatures to adopt old-age assistance and other welfare legislation or to modify existing laws, if necessary, cannot be doubted. Local taxes are too hard to raise to permit legislatures to resist the temptation to obtain donations from the central government. Most states will receive more than their citizens will pay in federal taxes and that will be a sufficient argument; and the pressure will be equally heavy upon the few states which will receive less-for to comply with the federal wish and receive something is cheaper than to remain aloof and yet contribute to other states. That the power to exercise such pressure upon the states in matters in which the federal government can admittedly not directly compel action is inimical to the dual system of government embedded in the Constitution seems clear. Its exercise, even with the best of motives, is on the borderline of constitutionality. On the whole, Title I and the other similar titles, are probably valid. Perhaps it would be more accurate to say that Title $I$ is, strictly, unconstitutional; but that it is within the tolerance permitted.

Whether the constitutionality of these titles will ever be tested is another question. Thus far, it has not been possible to bring a similar question before the Court. In a case in which the State of Massachusetts and an individual taxpayer sought to restrain the carrying out of the Maternity Act, $^{55}$ a law very similar in intention and in detail to Title I of the Social Security Act, upon the ground that it was unconstitu-

\footnotetext{
${ }^{54}$ See Linder v. U. S., 268 U. S. 5 (1925).
} ${ }^{25}$ STAT. 224 (I92I). 
tional, the Court expressly declined to pass on the constitutional question involved, holding that the Court was without jurisdiction to entertain a suit raising this question, whether it be brought by a state or by an individual taxpayer. With respect to the suit brought by the state, the Court held that

"Probably it would be sufficient to point out that the powers of the State are not invaded, since the statute imposes no obligation, but simply extends an option which the State is free to accept or reject. ...

"... If Congress enacted [the statute] with the ulterior purpose of tempting [the States] to yield, that purpose may be effectually frustrated by the simple expedient of not yielding."

In view of this, the Court held that there was no "controversy" over which the Court could take jurisdiction.

As to the suit brought by the individual taxpayer, the Court also held that it could not entertain jurisdiction, on the ground that the interest of the individual taxpayer

"is shared with millions of others; is comparatively minute and indeterminable; and the effect upon future taxation, of any payment out of the funds, so remote, fluctuating and uncertain, that no basis is afforded for an appeal to the preventive powers of a court of equity." 57

In addition, the Court stated that the matter was of "public, and not individual, concern" and that suit by individual taxpayers would result in great inconvenience.

The foregoing case was decided by a unanimous Court; and it may be assumed that the Court will come to the same conclusion with respect to any appropriation which, on the one,hand, clearly falls within the welfare clause, and which, on the other hand, does not clearly seek indirectly to regulate matters of local concern. On principle, however, the decision of the Court in that case, to the effect that an individual taxpayer has no standing to enjoin an appropriation of Congress, is of extremely doubtful soundness; and, especially after the decision of the Court in the $A$. A. A. case, in which the Court held that Congress cannot exert economic pressure upon an individual to induce him to act as it desires him to act, the Court may not follow its previous decision if there should be presented for consideration a situation in which the appropriating act clearly goes beyond an appropriation upon reasonable conditions, and seeks to coerce or to "purchase" compliance by the states with federal wishes.

To summarize: all of the provisions of the Social Security Act with respect to unemployment insurance and to compulsory federal old-age pensions are void, since they are not an exercise of any federal power and are an invasion of matters reserved to the states; the grants-in-aid are probably constitutional, but their validity will even more probably never be tested.

${ }^{50}$ Massachusetts v. Mellon, 262 U. S. $447,480,482$ (1923).

"Frothingham v. Mellon, id. at 487 . 